ORIGINAL ARTICLE

\title{
Effects of dominant somatotype on aerobic capacity trainability
}

\author{
M Chaouachi, A Chaouachi, K Chamari, M Chtara, Y Feki, M Amri, F Trudeau
}

Br J Sports Med 2005;39:954-959. doi: 10.1136/bjsm.2005.019943

See end of article for authors' affiliations

Correspondence to Mustapha Chaouachi, Laboratoire de Physiologie de la Nutrition, Faculté des Sciences de Tunis, El Manar 1060, Tunis, Tunisia; mustapha. chaouachi@issep-ks.rnu.tn

Accepted 9 May 2005
Purpose: This study examined the association between dominant somatotype and the effect on aerobic capacity variables of individualised aerobic interval training.

Methods: Forty one white North African subjects (age $21.4 \pm 1.3$ years; $\dot{V}_{2 \max }=52.8 \pm 5.7 \mathrm{ml} \mathrm{kg}^{-1}$ $\mathrm{min}^{-1}$ ) performed three exercise tests 1 week apart (i) an incremental test on a cycle ergometer to determine $\dot{V}_{o_{2 m a x}}$ and $\dot{V}_{o_{2}}$ at the second ventilatory threshold (VT2); (ii) a VAM-EVAL track test to determine maximal aerobic speed ( $\left.v \dot{V}_{o_{2 m a x}}\right)$; and (iii) an exhaustive constant velocity test to determine time limit performed at $100 \% v^{\circ} o_{2 m a x}(t l i m 100)$. Subjects were divided into four somatometric groups: endomorphs-mesomorphs (Endo-meso; $n=9$ ), mesomorphs (Meso; $n=11$ ), mesomorphs-ectomorphs (Meso-ecto; $n=12$ ), and ectomorphs (Ecto; $n=9$ ). Subjects followed a 12 week training program (two sessions/week). Each endurance training session consisted of the maximal number of successive fractions for each subject. Each fraction consisted of one period of exercise at $100 \%$ of $v \dot{V}_{o_{2 m a x}}$ and one of active recovery at $60 \%$ of $v \dot{V}_{o_{2 m a x}}$. The duration of each period was equal to half the individual tim 100 duration $(153.6 \pm 39.7 \mathrm{~s})$. After the training program, all subjects were re-evaluated for comparison with pre-test results.

Results: Pre- and post-training data were grouped by dominant somatotype. Two way ANOVA revealed significant somatotype-aerobic training interaction effects $(p<0.001)$ for improvements in $v \dot{V}_{o_{2 m a x}}$ $\dot{V}_{o_{2 m a x}}$ expressed classically and according to allometric scaling, and $\dot{V}_{o_{2}}$ at VT2. There were significant differences among groups post-training: the Meso-ecto and the Meso groups showed the greatest improvements in aerobic capacity.

Conclusion: The significant somatotype-aerobic training interaction suggests different trainability with intermittent and individualised aerobic training according to somatotype.
$\mathrm{T}$ here is great interest in systematically studying the factors that can influence fitness development for better sporting performance. ${ }^{1}$ Most available methods of measuring endurance training efficacy use maximal oxygen uptake $\left(\dot{\mathrm{V}}_{2 \max }\right)$ as the main outcome variable. However, it has been shown that $\dot{\mathrm{V}}_{2 \max }$ is not the only indicator of cardiorespiratory fitness for endurance events. ${ }^{1} \dot{V}_{\mathrm{O}_{2 \max }}$ must be associated with other factors such as ventilatory threshold (VT), velocity at $\dot{V}_{\mathrm{O}_{2 \max }}$ and exercise economy to explain differences in endurance performance. ${ }^{2}$

Several studies relating to the effect of interval training on aerobic fitness indicate that cardiorespiratory adaptation depends mainly on the initial fitness level of the subjects, the training intensity, the frequency of training sessions, and the duration of the training sessions and programs. ${ }^{3}$ Genetic factors explain part of the variability in adaptation to a given training program and should be considered. ${ }^{4}$ The contribution of morphological factors, such as somatotype, to athletic performance has also been studied. Indeed, anthropological studies of Olympic athletes characterised the typical somatotype associated with performance in specific athletic events. ${ }^{5}$ However, few have explored physiological adaptation to training in relation to morphological factors. Some authors have shown that the dominant somatotype influences functional responses at peak exercise. ${ }^{67}$ Ergen et al found no correlation between somatotype components and maximal alactic anaerobic power in trained subjects. Nevertheless, it is still questioned whether dominant somatotype is directly related to improvements in aerobic capacity variables.

Investigations by Berg et al to determine the best predictors of $10 \mathrm{~km}$ running time, have shown that the somatotype and anthropometric traits of athletes contribute significantly to variance in endurance performance. However, the main physiological determinants of running endurance performance, that is $\dot{\mathrm{V}}_{2 \max }$, the second $\mathrm{VT}$, exercise economy, and velocity at $\dot{\mathrm{V}}_{2 \text { max }}$, were not included in the study's stepwise multiple regression analysis. Furthermore, the influence of somatotype on aerobic fitness trainability was not considered.

The aim of the present study was therefore to investigate the interaction between somatotype and the adaptation of the key aerobic capacity variables to individualised intermittent aerobic training in male white North African students.

\section{METHODS \\ Subjects}

Forty one fit physical education students volunteered to participate in this study. They did not practice any sport but undertook $\sim 10 \mathrm{~h}$ per week of various physical activities as part of their university course. Aged $21.4 \pm 1.3$ years, they were divided into four somatometric groups (fig 1). Body composition was estimated from skinfold thickness. ${ }^{10}$ The anthropometric characteristics are presented in table 1. The study was approved by the University Ethics Committee. After receiving a detailed explanation of the potential benefits and risks associated with participation in the study,

Abbreviations: ACE, angiotensin converting enzyme; ANCOVA, analysis of covariance; ANOVA, analysis of variance; $\mathrm{HR}$, heart rate; $\mathrm{RER}$, respiratory exchange ratio; $\mathrm{V}_{\mathrm{O}_{2 m a x}}$ maximal oxygen uptake; VT, ventilatory threshold 


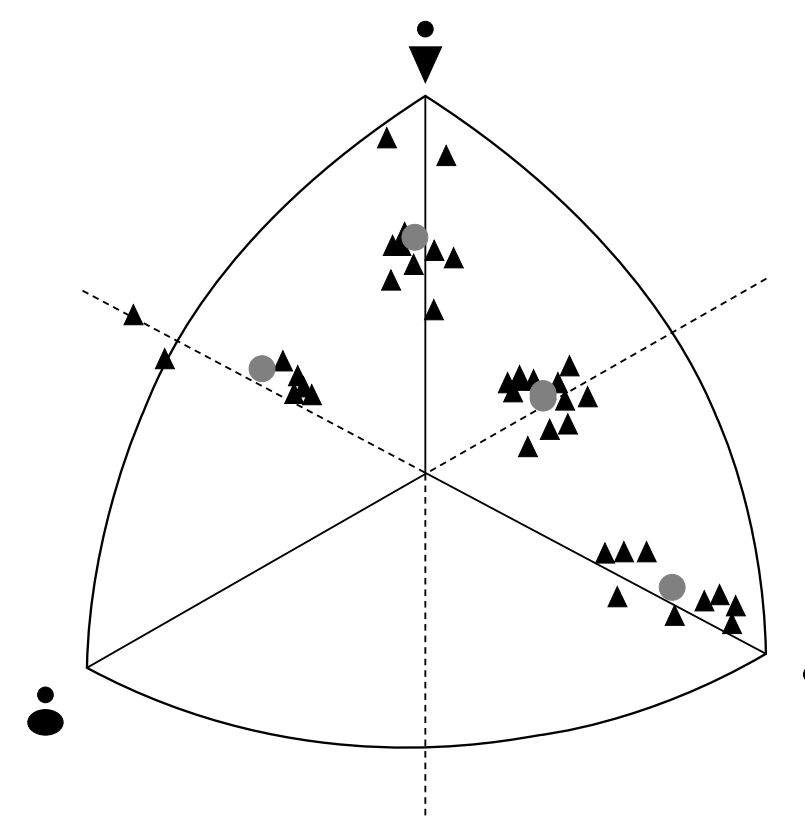

Figure 1 Individual somatoplots (triangles) with mean somatotype for each category (circles).

each student gave his informed consent. All subjects were white North Africans from Tunisia.

\section{Protocol}

All subjects underwent an identical battery of tests before and after the 12 week training program. The pre- and posttests included anthropometric measurements, and laboratory and field tests.

Individual somatotypes were assessed according to the Heath-Carter anthropometric method rounded to the nearest half-unit rating. ${ }^{11}$ This method provides an anthropometric rating of physique and shows the relative dominance of the three following components: (i) endomorphy (component I) refers to relative fatness and is derived from the sum of three skinfolds: triceps, subscapular, and supraspinal; (ii) mesomorphy (component II) relates to relative robustness development, and is derived from bi-epicondylar femur and humerus widths, and arm and calf circumferences corrected for the site specific skinfold thickness; and (iii) ectomorphy (component III) refers to relative linearity and is based on the stature-body mass ratio (stature divided by the cube root of body mass or $\mathrm{kg} \mathrm{m}^{-1 / 3}$ ). All skinfolds and girths were recorded by the same examiner. Each skinfold was measured three times with a skinfold calliper (Lange, Cambridge, MA, USA). The average of the three measurements for each site was considered in the calculation. The right side values for skinfolds, girths, and diameters were included in the calculations according to the method described by Ross et al. ${ }^{12}$

Each subject performed three preliminary tests 1 week apart. The first test measured $\dot{\mathrm{V}}_{2 \text { max }}$ and was performed in the laboratory. The second test, that is the VAM-EVAL track test, ${ }^{13}$ measured maximal aerobic speed $\left(v \dot{\mathrm{V}}_{2 \text { max }}\right)$, and the third test assessed the time to exhaustion at $100 \% v \dot{\mathrm{V}}_{2 \max }$ on the running track (tlim100).

\section{$\dot{V}_{2 \text { max }}$ measurement}

Individual $\dot{\mathrm{V}}_{2 \max }$ was measured during a continuous, incremental test to exhaustion ${ }^{14}$ on an electronically braked cycle ergometer (Monark Ergometrics 800, Bitz, Germany). Prior to the test, the subjects underwent clinical examination to check their health status. Respiratory parameters $\left(\dot{\mathrm{V}}_{2}\right.$, $\mathrm{CO}_{2}$ ) and respiratory exchange ratio (RER) were measured continuously (ZAN 680, Oberthulba, Germany) during the initial resting period and throughout the test until exhaustion. The gas analysers were calibrated before each test with gases of known concentrations. Heart rate (HR) was recorded with an ECG monitoring system. The following criteria ${ }^{15}$ indicated $\dot{\mathrm{V}}_{2 \max }$ had been attained: (i) a plateau or slight drop in $\dot{\mathrm{V}}_{2}$ despite an increase in workload; (ii) exhaustion; (iii) an RER above 1.1; and (iv) an HR above $95 \%$ of predicted maximal HR. The second ventilatory threshold (VT2) ${ }^{16}$ and maximal oxygen pulse $\left(\mathrm{O}_{2}\right.$ pulse $)$ were then quantified. VT2 was assessed independently by two experienced individuals who then compared their results and reached a consensus. VT2 was expressed in $\dot{\mathrm{V}}_{2}\left(\mathrm{ml} \mathrm{kg}^{-1} \mathrm{~min}^{-1}\right)$ and as a fraction of $\dot{\mathrm{V}}_{2 \max }\left(\% \dot{\mathrm{V}}_{2 \max }\right)$. Maximal $\mathrm{O}_{2}$ pulse $\left(\mathrm{ml}\right.$ beats $\left.{ }^{-1}\right)$ was

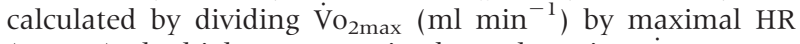
$\left(\mathrm{HR}_{\max }\right)$, the highest $\mathrm{HR}$ attained at exhaustion. $\dot{\mathrm{V}}_{2 \max }$ was expressed classically and according to allometric scaling to avoid underestimation in heavy and overestimation in light individuals. ${ }^{17}$

\section{VAM-EVAL track test}

The VAM-EVAL track test $\mathrm{t}^{13}$ took place on a $400 \mathrm{~m}$ track with cones placed every $20 \mathrm{~m}$. A pre-recorded soundtrack indicated with brief sounds the instant when the subject had to pass near a cone to maintain the imposed speed. A longer sound marked a change of stage. The first stage was set at $8 \mathrm{~km} \mathrm{~h}^{-1}$ with subsequent increments of $0.5 \mathrm{~km} \mathrm{~h}^{-1}$ per 1 min stages. The test was finished when the subject was unable to maintain the imposed running speed. The speed corresponding to the last completed stage was recorded as $v \dot{\mathrm{V}}_{2 \max }\left(\mathrm{km} \mathrm{h}^{-1}\right)$.

Time to exhaustion at $100 \% v \dot{V} o_{2 \max }(t \lim 100)$

The purpose of the third field session was to estimate the individual running performance at $100 \% v \dot{\mathrm{V}}_{2 \max }$ (tlim 100). ${ }^{18}$ The test took place on the same track described above. After a

Table 1 Physical characteristics of each group separated according to somatotype

\begin{tabular}{lllll}
\hline Somatotype characteristics & Endo-meso, $\mathbf{n = 9}$ & Meso, $\mathbf{n = 1 1}$ & Meso-ecto, $\mathbf{n = 1 2}$ & Ecto, $\mathbf{n = 9}$ \\
\hline Body mass $(\mathrm{kg})$ & $77.7 \pm 6.1$ & $72.3 \pm 4.7$ & $66.4 \pm 2.0$ & $65.5 \pm 3.6$ \\
Height $(\mathrm{cm})$ & $178.9 \pm 5.6$ & $175.3 \pm 4.3$ & $176.0 \pm 2.3$ & $184.8 \pm 6.1$ \\
Body fat (\%) & $20.6 \pm 2.2$ & $14.0 \pm 1.4$ & $11.8 \pm 1.6$ & $11.4 \pm 0.5$ \\
Fat mass (kg) & $16.0 \pm 2.1$ & $10.1 \pm 1.2$ & $7.8 \pm 1.1$ & $7.5 \pm 0.5$ \\
Lean mass (kg) & $61.7 \pm 5.2$ & $62.2 \pm 4.1$ & $58.6 \pm 2.3$ & $19.2 \pm 0.4$ \\
BMl (kg m-2) & $24.2 \pm 1.0$ & $23.5 \pm 0.5$ & $21.4 \pm 0.4$ & $1.7 \pm 0.2$ \\
Endomorphy & $4.1 \pm 0.5$ & $2.3 \pm 0.2$ & $1.8 \pm 0.2$ & $2.0 \pm 0.2$ \\
Mesomorphy & $4.1 \pm 0.3$ & $4.8 \pm 0.6$ & $3.3 \pm 0.2$ & $5.0 \pm 0.5$ \\
Ectomorphy & $2.1 \pm 0.5$ & $2.2 \pm 0.2$ & $3.2 \pm 0.2$ & \\
\hline
\end{tabular}

BMI, body mass index; Ecto, ectomorph; Endo-meso, endomorph-mesomorph; Meso, mesomorph; Meso-ecto, mesomorph-ectomorph. Values are expressed as mean $\pm S D$. 
15 min warm up at $60 \% v \dot{\mathrm{V}} \mathrm{O}_{2 \text { max }}$, the subjects had to run for as long as possible at a pace corresponding to their $v \dot{\mathrm{V}}_{2 \text { max }}$. The post-training tlim 100 was performed at the pre-training $v \dot{\mathrm{V}} \mathrm{O}_{2 \max }$.

\section{Training}

The training program lasted 12 weeks with two sessions per week, and consisted of individualised intermittent running. Each training session began with a 20 min warm up at $60 \%$ of each subject's $v \dot{\mathrm{V}}_{2 \max }$. The session itself was composed of the maximal number of running fractions that each subject was able to perform. Each fraction consisted of one period of running at $100 \%$ of $v \dot{\mathrm{V}}_{2 \text { max }}$ and one period of active recovery at $60 \%$ of $v \dot{\mathrm{V}}_{2 \text { max }}$. The duration of each period was equal to half the individual tliml00 duration. ${ }^{19}$ To establish the maximal number of fractions that each subject could perform during a session, an individualised test was performed before the start of the training program. Thus, the training program was individualised both for the running speed for intervals and for the number of fractions. ${ }^{20}$ The intensities of the periods of exercise and recovery were readjusted after 6 weeks by way of a VAM-EVAL test (intermediate $v \dot{\mathrm{V}}_{2 \text { max }}$ ). After training, $\dot{\mathrm{V}}_{\mathrm{O}_{2 \max }}$ $v \dot{\mathrm{V}} \mathrm{O}_{2 \text { max }}$, and tliml00 (performed at the pre-training $v \dot{\mathrm{V}}_{2 \text { max }}$ ) were measured for each subject.

\section{Statistical analysis}

A somatochart was developed with Somatotype 1.0 software to determine the somatotypes (fig 1). Four distinct groups emerged with nine endomorph-mesomorph (Endo-meso), 11 mesomorph (Meso), 12 mesomorph-ectomorph (Meso-ecto), and nine ectomorph subjects (Ecto). The data were grouped by dominant somatotype and descriptive statistics were expressed as mean $\pm \mathrm{SD}$. The hypothesis that somatotype impacts improvements in aerobic fitness variables was tested for significance at an $\alpha=0.05$ level by two way analysis of variance (ANOVA) for repeated measures. An analysis of covariance (ANCOVA) was used post hoc to compare means for each variable in the presence of significant somatotypeaerobic training period interaction effects. Differences between pre- and post-training mean values were evaluated for significant $(\mathrm{p}<0.05)$ changes from 0 by the paired Wilcoxon test (SPSS 10.0).

\section{RESULTS}

ANOVA indicated significant training effects for all physiological variables from pre- to post-training within groups $(p<0.001)$ except for maximal HR (table 2). A significant (somatotype $\times$ pre- and post-training) interaction effect $(p<0.001)$ was observed. This interaction mainly concerned $v \dot{\mathrm{V}}_{2 \max }, \dot{\mathrm{V}}_{2 \max }$ expressed in $\mathrm{ml} \mathrm{kg}^{-1} \mathrm{~min}^{-1}$ and $\mathrm{ml} \mathrm{kg}^{-0.75}$ $\min ^{-1}$, and $\dot{\mathrm{V}}_{2}$ at VT2 (fig 2).

\section{$v \dot{V} o_{2 \max }$ and $\operatorname{tim} 100$}

$v \dot{\mathrm{V}}_{2 \text { max }}$ increased significantly in the four groups after the training period (table 2 ). Significant (somatotype $\times$ pre- and post-training) interaction effects $(F=9.70$ ( $\mathrm{df}$ 1, 37); $\mathrm{p}<0.001)$ were also observed. Meso-ecto subjects showed the greatest increment in $v \dot{\mathrm{V}}_{2 \text { max }}$. Significant elevation of tlim 100 (performed at the pre-test $v \dot{\mathrm{V}}_{2}$ max ) was evident for all somatotype groups (table 2), but the mean increases were not significantly different between groups.

\section{$\dot{V}_{2 \max }$}

Both absolute $\left(\mathrm{l} \mathrm{min}^{-1}\right)$ and relative $\dot{\mathrm{V}}_{2 \max }\left(\mathrm{ml} \mathrm{kg}^{-1} \mathrm{~min}^{-1}\right.$ and $\mathrm{ml} \mathrm{kg}^{-0.75} \mathrm{~min}^{-1}$ ) increased significantly in the four groups except for absolute $\dot{\mathrm{V}}_{2 \max }$ in Endo-meso subjects which only showed a trend towards significance $(p=0.08$, table 2). However, interaction effects (somatotype $\times$ pre- and post-training) were significant $(F=22.7(\mathrm{df} 1,37) ; \mathrm{p}<0.001)$
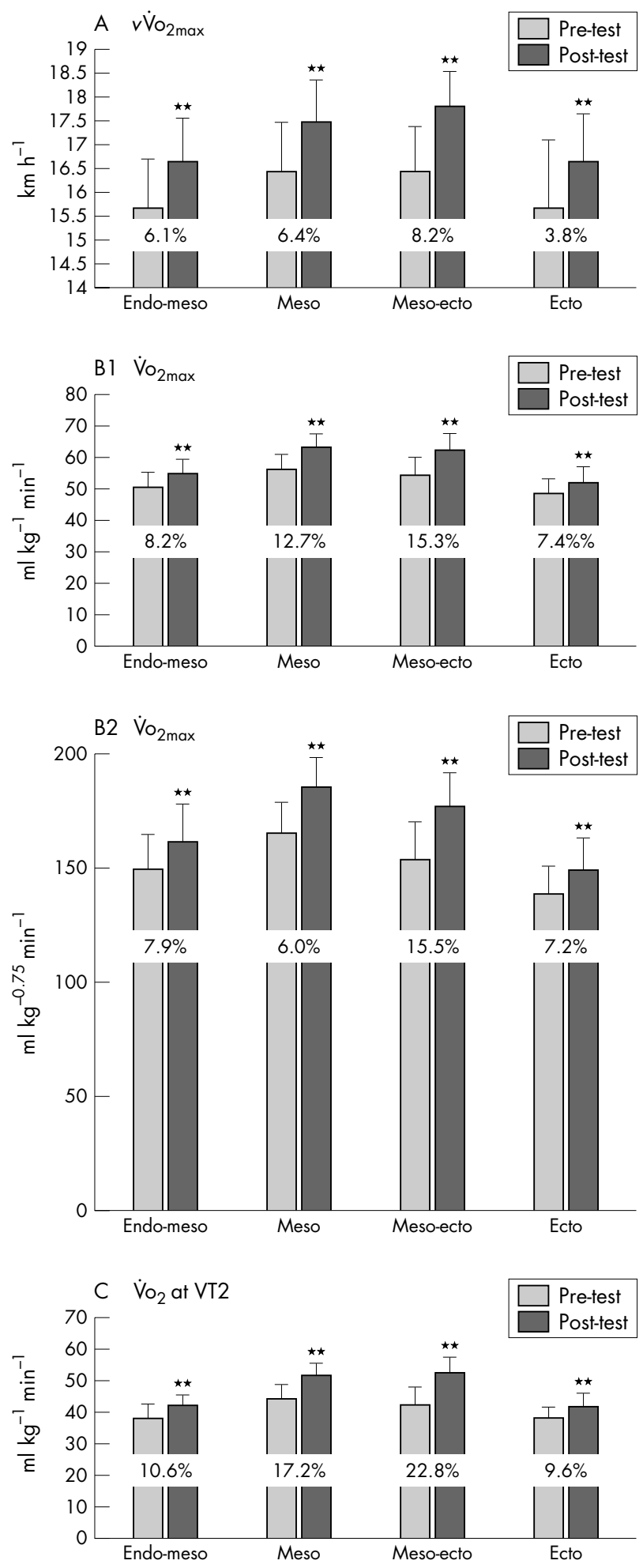

Figure 2 Somatotype-aerobic training interaction effects on cardiorespiratory parameters. The numbers on the columns represent the percentage of change from test to retest; ${ }^{* *} p<0.01$. For legends, see table 1.

only for relative $\dot{\mathrm{V}} \mathrm{O}_{2 \max }\left(\mathrm{ml} \mathrm{kg}{ }^{-1} \mathrm{~min}^{-1}\right.$ and $\mathrm{ml} \mathrm{kg}^{-0.75}$ $\min ^{-1}$ ). The Meso-ecto and Meso groups experienced significantly greater improvements than the other groups (fig 2B1,B2). 
Table 2 Effects of 12 week training program on components of aerobic capacity in somatotype groups

\begin{tabular}{|c|c|c|c|c|c|c|c|}
\hline & & \multirow{2}{*}{$\begin{array}{l}\text { Endo-meso, } \\
n=9\end{array}$} & \multirow{2}{*}{$\begin{array}{l}\text { Meso, } \\
n=11\end{array}$} & \multirow{2}{*}{$\begin{array}{l}\text { Meso-ecto, } \\
n=12\end{array}$} & \multirow{2}{*}{$\begin{array}{l}\text { Ecto, } \\
n=9\end{array}$} & \multirow{2}{*}{$\begin{array}{l}\text { Total, } \\
n=41\end{array}$} & \multirow{2}{*}{$\begin{array}{l}\text { Interaction } \\
\text { df } 1,37\end{array}$} \\
\hline & & & & & & & \\
\hline \multirow{2}{*}{$v \dot{V}_{o_{\text {max }}}\left(\mathrm{km} \mathrm{h}^{-1}\right)$} & Pre-test & $15.7 \pm 1.0$ & $16.4 \pm 1.0$ & $16.4 \pm 0.9$ & $16.2 \pm 0.9$ & $16.2 \pm 1.0$ & $F=9.7$ \\
\hline & Post-test & $16.6^{\star *} \pm 0.9$ & $17.5^{\star \star} \pm 0.9$ & $17.8^{\star \star} \pm 0.7$ & $16.9^{\star \star} \pm 0.8$ & $17.2^{\star *} \pm 0.9$ & ** \\
\hline \multirow[t]{2}{*}{ tlim100 (s) } & Pre-test & $345.6 \pm 70.0$ & $306.8 \pm 64.5$ & $298.4 \pm 103.8$ & $280.9 \pm 64.1$ & $307.2 \pm 79.5$ & $F=1.5$ \\
\hline & Post-test & $443.6^{\star \star *} \pm 73.6$ & $410.2^{\star \star} \pm 52.4$ & $407.4^{\star \star} \pm 84.8$ & $344.7^{\star *} \pm 54.0$ & $402.3^{\star \star} \pm 74.0$ & NS \\
\hline \multirow[t]{2}{*}{$\dot{V}_{o_{\text {max }}}\left(\mid \min ^{-1}\right)$} & Pre-test & $3.9 \pm 0.5$ & $4.2 \pm 0.5$ & $3.5 \pm 0.5$ & $3.3 \pm 0.2$ & $3.7 \pm 0.6$ & $F=1.5$ \\
\hline & Post-test & $4.2 \pm 0.6$ & $4.7^{\bar{\star}} \pm 0.6$ & $4.1^{\bar{\star}} \pm 0.4$ & $3.5^{\star \star} \pm 0.2$ & $4.1^{\star \star} \pm 0.6$ & NS \\
\hline $\begin{array}{l}\dot{V} o_{2 m a x} \\
\left(\mathrm{ml} \mathrm{kq}^{-1} \min ^{-1}\right)\end{array}$ & $\begin{array}{l}\text { Pre-test } \\
\text { Post-test }\end{array}$ & $\begin{array}{l}50.7 \pm 4.6 \\
54.9^{* *}+4.9\end{array}$ & $\begin{array}{l}56.4 \pm 4.7 \\
63.6^{* *}+4.2\end{array}$ & $\begin{array}{l}54.2 \pm 5.7 \\
62.5^{\star *}+5.2\end{array}$ & $\begin{array}{l}48.5 \pm 4.8 \\
52.1^{* *}+5.3\end{array}$ & $\begin{array}{l}52.8 \pm 5.7 \\
58.8^{\star *}+6.8\end{array}$ & $F=22.6$ \\
\hline $\begin{array}{l}\mathrm{V}_{2 \max } \\
\left(\mathrm{ml} \mathrm{kg}^{-0.75} \mathrm{~min}^{-1}\right)\end{array}$ & $\begin{array}{l}\text { Pre-test } \\
\text { Post-test }\end{array}$ & $\begin{array}{l}150.0 \pm 14.8 \\
161.9^{* *}+16.3\end{array}$ & $\begin{array}{l}165.3 \pm 13.5 \\
186.1^{* *}+13.1\end{array}$ & $\begin{array}{l}153.8 \pm 17.1 \\
177.8^{\star *}+14.6\end{array}$ & $\begin{array}{l}138.9 \pm 12.2 \\
149.0^{* *}+13.3\end{array}$ & $\begin{array}{l}152.8 \pm 17.0 \\
170.2^{* *}+20.0\end{array}$ & $\begin{array}{l}F=13.4 \\
* *\end{array}$ \\
\hline & Pre-test & $38.1 \pm 4 . \overline{7}$ & $44.2 \pm 4.3$ & $42.7 \pm 5.7$ & $38.1 \pm 3.7$ & $41.1 \pm 5.3$ & $F=16.32$ \\
\hline$\left(\mathrm{ml} \mathrm{kg}{ }^{-1} \min ^{-1}\right)$ & Post-test & $42.2^{\star \star} \pm 3.7$ & $51.8^{\star \star} \pm 4.0$ & $52.4^{\star \star} \pm 5.2$ & $41.8^{\star \star} \pm 4.4$ & $47.7^{\star \star} \pm 6.6$ & \\
\hline \multirow[t]{2}{*}{$\% \dot{\mathrm{V}}_{\mathrm{O}_{\text {max }}}$} & Pre-test & $75.1 \pm 4.5$ & $78.4 \pm 4.6$ & $78.7 \pm 6.7$ & $78.6 \pm 2.1$ & $77.8 \pm 5.0$ & $F=1.8$ \\
\hline & Post-test & $76.9 \pm 3.4$ & $81.4^{\star \star} \pm 3.2$ & $83.8^{\star \star} \pm 2.8$ & $80.1^{\star \star} \pm 1.5$ & $80.9^{* \star} \pm 3.7$ & NS \\
\hline HR max & Pre-test & $184 . \overline{7} \pm 9.2$ & $190.7 \pm 6.5$ & $187.3 \pm 7.5$ & $191.1 \pm 7.7$ & $188.5 \pm 7.8$ & $F=2.07$ \\
\hline (beats $\min ^{-1}$ ) & Post-test & $187.4 \pm 9.8$ & $191.4 \pm 5.6$ & $187.7 \pm 7.0$ & $190.1 \pm 5.7$ & $189.1 \pm 7.0$ & NS \\
\hline Maximal $\mathrm{O}_{2}$ pulse & Pre-test & $21.1 \pm 2.7$ & $22.0 \pm 3.2$ & $18.8 \pm 3.0$ & $17.1 \pm 1.7$ & $19.8 \pm 3.3$ & $F=1.5$ \\
\hline$\left(\mathrm{ml} \text { beat }^{-1}\right)^{-}$ & Post-test & $22.3 \pm 3.4$ & $24.5^{\star \star} \pm 2.8$ & $21.8^{\star \star} \pm 2.5$ & $18.3^{\star *} \pm 1.6$ & $21.9^{\star \star} \pm 3.4$ & NS \\
\hline
\end{tabular}

\section{$\dot{\mathrm{V}} \mathrm{o}_{2}$ at VT2}

Oxygen uptake at VT2 expressed in $\mathrm{ml} \mathrm{kg}^{-1} \mathrm{~min}^{-1}$ and in percentage of $\dot{\mathrm{V}}_{2 \max }\left(\% \dot{\mathrm{V}}_{2 \max }\right)$ showed a significant increase pre- to post-training for all groups except for $\% \dot{\mathrm{V}}_{2 \max }$ in the Endo-meso group (table 2). However, interaction effects (somatotype $\times$ pre- and post-training) were significant $(F=16.3$ (df 1,37$) ; \mathrm{p}<0.001)$ only in VT2 expressed in $\mathrm{ml} \mathrm{min}^{-1} \mathrm{~kg}^{-1}$; the Meso-ecto group presented a significantly higher mean of increases compared to the other groups.

\section{Maximal $\mathrm{O}_{2}$ pulse}

No significant interaction effects (somatotype $\times$ pre- and posttraining) were noted. However, there was a significant improvement in all somatotype subjects from pre- to posttraining (table 2) except for the Endo-meso group.

\section{DISCUSSION}

The results of this study showed the effects of somatotype on adaptation of aerobic capacity to individualised aerobic interval training in white North African male students. The variations in aerobic capacity variables demonstrated a significant interaction effect with somatotype over a period of aerobic training. The magnitude of increase in these parameters varied according to somatotype group. Indeed, as a result of training, $v \dot{\mathrm{V}}_{2 \text { max }}, \dot{\mathrm{V}}_{\mathrm{O}_{2 \max }}\left(\mathrm{ml} \mathrm{kg}^{-1} \mathrm{~min}^{-1}\right.$ and $\mathrm{ml}$ $\left.\mathrm{kg}^{-0.75} \min ^{-1}\right)$, and $\dot{\mathrm{V}}_{2}$ at VT2 improved in all training groups, with the Meso-ecto and Meso groups showing the highest training gains.

The objective of the interval training program was mainly to elicit optimal improvements in aerobic capacity variables. The frequency, intensity, and duration of the training program were established as essential components in promoting adaptive responses to training. ${ }^{21}$ Individual $v \dot{\mathrm{V}}{ }_{2 \text { max }}$ was considered as a relevant criterion to set training intensities. In the present study, $v \dot{V}_{O_{2 m a x}}$ measurement in the field, for training purposes, was preferred to laboratory measurements. ${ }^{22}$ The time for which exercise at $v \dot{\mathrm{V}}_{2 \max }$ could be sustained (tlim100) was used to individualise the duration of interval training at $v \dot{\mathrm{V}}_{2 \max }$ according to the method of Billat et al. ${ }^{19}$ The number of repetitions performed by subjects in the previously individualised intermittent protocols varied from 2 to 5 . The mean values recorded by Billat et $a l^{19}$ in long distance runners were $5.5 \pm 2.0$ repetitions. This is the reason why the number of repetitions in training sessions was individualised and not standardised.
The post-training improvements in relative $\dot{\mathrm{V}}_{2 \max }(\mathrm{ml}$ $\mathrm{kg}^{-1} \mathrm{~min}^{-1}$ ) were significantly higher for the Meso-ecto and Meso groups ( $15.3 \%$ and $12.7 \%$, respectively) than for the other groups (fig 2B1,B2). These mean gains are consistent with values found in other training studies which have reported increases ranging from $10 \%$ to $23 \% .{ }^{202324}$ Increments in $\dot{\mathrm{V}}_{2 \max }$ could be explained by augmented stroke volume, and by enhanced potential for widening the arterial-venous oxygen difference during exercise and/or by both factors. ${ }^{25}$ The improvements in relative $\dot{\mathrm{V}}_{2 \max }\left(\mathrm{ml} \mathrm{kg}^{-1}\right.$ $\mathrm{min}^{-1}$ and $\mathrm{ml} \mathrm{kg}^{-0.75} \mathrm{~min}^{-1}$ ) in the present study could be due to improved capacity of the cardiorespiratory system and not to any change in body mass. The rise in $\mathrm{O}_{2}$ pulse following the training period may reflect the extent of cardiac and peripheral adaptation to training. ${ }^{26}$ The highest increases were observed in the Meso (11.4\%) and Meso-ecto groups $(15.9 \%)$ in comparison to the Endo-meso $(5.6 \%)$ and Ecto (7.3\%) groups.

The training program also induced a significant improvement in $v \dot{\mathrm{V}}_{2 \text { max }}$ (fig 2B). The magnitude of these increases (from $6.1 \%$ to $8.2 \%$ ) differed among somatotype groups. The Meso-ecto group showed the highest mean gains (8.2\%). This improvement in $v \dot{\mathrm{V}}_{2 \max }$ indicates that a certain percentage of $\dot{\mathrm{V}}_{2 \max }$ will be associated with higher speed after training. ${ }^{27}$ Several studies have reported increased $v \dot{\mathrm{V}}_{2 \text { max }}$ of between $2.9 \%$ and $8.5 \%$ in well trained athletes following endurance training. ${ }^{20} 290$ They found that this increase in $v \dot{\mathrm{V}}_{2 \text { max }}$ resulted from significant improvements in both $\dot{\mathrm{V}}_{2 \max }$ and running economy. In the present study, improvements in the former were shown while the latter variable was not measured.

$\dot{\mathrm{V}}_{2}$ at VT2 ( $\dot{\mathrm{V}}_{2}$ threshold) increased after training (fig 2C). However, there was a wide variation in the mean changes between groups (9.6\% to $22.8 \%$ ). Again, the Meso-ecto group achieved the highest increase. Similar results were obtained for $\dot{\mathrm{V}}_{2}$ at the second VT expressed in $\% \dot{\mathrm{V}}_{2 \text { max }}$. The highest values recorded in this somatotype group reached $83.8 \pm 2.8 \%$ of $\dot{\mathrm{V}}_{2 \max }$, with a significant gain of $6.4 \%$. Several studies have demonstrated the sensitivity of the VT to endurance training. ${ }^{31}{ }^{32}$ The significant improvements in this parameter could be explained by better enzymatic adaptation due to high intensity training, allowing subjects to exercise at a high percentage of $\dot{\mathrm{V}}_{2 \max }$ for prolonged periods. ${ }^{32}{ }^{33}$

The main findings of our study showed that the most significant improvements in aerobic capacity components following the training program varied among the dominant 
somatotype groups. Indeed, mean gains in $v \dot{\mathrm{V}}_{2 \text { max }}$, relative $\dot{\mathrm{V}}_{2 \max }$ (expressed per $\mathrm{ml} \mathrm{kg}^{-1} \mathrm{~min}^{-1}$ and per $\mathrm{ml} \mathrm{kg}^{-0.75}$ $\left.\min ^{-1}\right)$, and $\dot{\mathrm{V}}_{2}$ at VT2 were higher when the Meso and Ecto components were balanced as is the case in the Ecto-meso group. Improvements were slightly lower in subjects exhibiting a Meso dominance. Thus, a morphological type favouring cardiorespiratory adaptation to aerobic training seems to exist. Quantification of the contribution of the dominant somatotype to improvement in aerobic fitness is difficult. However, studies of monozygote and heterozygote twins and other subjects with familial similarities have shown appreciable genetic effects on somatotype, especially at the level of the Ecto component. ${ }^{34}$ On the other hand, $\dot{\mathrm{V}}_{2 \text { max }}$, an index of aerobic fitness, is influenced by genetic and environmental factors. ${ }^{35}$ Genetic factors indeed impact the development of $\dot{\mathrm{V}}_{\mathrm{O}_{2 \max }}$, but training allows its improvement. The same author showed that heredity largely influences the trainability of $\dot{\mathrm{V}}_{2 \text { max }}$. Depending on genotype, the same training program can have different effects, ranging from $0 \%$ to $30 \%{ }^{35}$ According to these studies, there is a potential association between genetic variables, such as muscular enzymes (that is mitochondrial DNA), and changes in $\dot{\mathrm{V}}_{2 \max }$ following training. Nevertheless, in contrast to somatotype determination, which is quite easy, studying the genetic type of an athlete is, at present, somewhat problematic. A new issue, which has recently been raised and could help explain differences in responses to endurance training, is the role played by the angiotensin converting enzyme gene (ACE) especially its I allele variant. ${ }^{36}$ One possible explanation for the great improvement in aerobic capacity in the Meso-ecto and Meso groups is the higher prevalence of the ACE gene insertion polymorphism in these groups.

In addition, somatotype-aerobic training interaction effects on improvement in aerobic capacity are also influenced by the relationship between $\dot{\mathrm{V}}_{2 \text { max }}$ and biometric data, such as body size, body mass, and body surface. Thus, the allometric approach is used to compare individuals of various dimensions and sizes. ${ }^{37}{ }^{38}$ Many studies have shown that relative $\dot{\mathrm{V}}_{2 \text { max }}$ is negatively correlated to body mass. ${ }^{39}$ However, it also appears important to consider how segments are distributed. As indicated by Cavanagh and Kram as regards running ${ }^{40}$ a higher energy cost was recorded when the lower limbs were heavier. Body dimensions also influence running energy cost, but a relatively conflicting report has been presented on this topic. ${ }^{41}$ These factors should be considered by researchers attempting to further explain the interaction between somatotype and the effect of aerobic training. Fat mass also may have influenced aerobic capacity. Most studies have reported that high levels of adiposity reduce aerobic capacity expressed relative to body mass. ${ }^{42}$ Finally, differences in ethnic/racial origins should also be taken into account when interpreting the results of subjects differing in racial origin. This point is not addressed in the present study because all subjects were of the same background. Moreover, somatotype measurement is based on several criteria which are independent of ethnic origin. To the best of our knowledge and according to the literature, there are no differences in trainability between black and white subjects of the same somatotype group.

The results of our investigation suggest that somatotype may partly explain the variance in physiological adaptive responses to aerobic interval training. Anthropometric traits which characterise the Meso-ecto and Meso somatotype subjects may explain these differences. However, it seems that genetic factors play a considerable role in the expression of physiological adaptation to which the somatotype-training association may make an important contribution.

In conclusion, the results of the present study indicate significant somatotype-aerobic training interaction effects

\section{What is already known on the topic}

The contribution of morphological factors, such as somatotype, to athletic performance has been widely studied. Some authors have shown the influence of dominant somatotype on functional responses at peak exercise. However, few have explored the influence of morphological factors on physiological adaptation to training.

\section{What this study adds}

The results suggest that somatotype may partly explain the variance in physiological adaptive reponses to interval training. Aerobic capacity variables demonstrated significant interaction effects with somatotype over a period of aerobic training. The mesomorph and the mesomorph-ectomorph subjects demonstrated greater improvements in aerobic capacity following aerobic training.

that may make an important contribution to the establishment of an adaptive response to intermittent and individualised aerobic training. Somatotype mainly influenced gains in aerobic capacity, particularly $v \dot{\mathrm{V}}_{2 \max }$, relative $\dot{\mathrm{V}}_{\mathrm{O}_{2 \max }}$, and relative $\dot{\mathrm{V}}_{2}$ at the second VT. Significant post-training differences among groups were observed; Meso-ecto and Meso subjects seemed to be particularly predisposed to benefit from aerobic training. The relationship of aerobic fitness trainability to somatotype and genetic factors warrants further investigation.

\section{Conclusions}

This study demonstrates that somatotype is a structural factor in aerobic fitness trainability and could be helpful when identifying talented individuals for endurance events. Nevertheless, it is not easy to establish with precision the contribution of somatotype-training interaction effects to aerobic capacity determinants. Many factors, including genetic contribution, may be determinants of both somatotype and the capacity to adapt to training; this could be further investigated.

\section{ACKNOWLEDGEMENTS}

This study was financially supported by the Ministère de la Recherche Scientifique, de la Technologie et du Développement des Compétences, Tunisia.

\section{Authors' affiliations}

M Chaouachi, M Chtara, Y Feki, M Amri, Laboratoire de Physiologie de la Nutrition, Faculté des Sciences de Tunis, El Manar 1060 Tunis, Tunisia A Chaouachi, K Chamari, Centre National de la Médecine et des Sciences du Sport, Unité de Recherche "Evaluation, Sport, Santé", CNMSS, El Menzah, Tunisia

F Trudeau, Département des Sciences de l'Activité Physique, Université du Québec à Trois-Rivières, Québec, Canada

Competing interests: none declared

\section{REFERENCES}

1 Myburgh KH. What makes an endurance athlete world-class? Not simply a physiological conundrum. Comp Biochem Physiol A Mol Integr Physiol 2003;136:171-90.

2 Whipp BJ, Ward SA, Lamarra N, et al. Parameters of ventilatory and gas exchange dynamics during exercise. J Appl Physiol 1982;52:1506-13.

3 Mikesell KA, Gary AD. Influence of intense endurance training on aerobic power of competitive distance runners. Med Sci Sports Exerc 1984; 16(4):371-5.

4 Bouchard C, Dionne FT, Simoneau JA, et al. Genetics of aerobic and anaerobic performance. Exerc Sport Sci Rev 1992;20:27-58. 
5 Carter JEL, Aubrey SP, Sleet DA. Somatotypes of Montreal Olympic athletes. Med Sport 1982; 16:53-80.

6 Schreiber ML. Anaerobic capacity as a function of somatotype and participation in varsity athletics. Res Q 1973;44(2):197-205.

7 Bolonchuk WW, Siders WW, Lykken GI, et al. Association of dominant somatotype of men with body structure, function during exercise and nutritional assessment. Am J Hum Biol 2000;12:167-80.

8 Ergen E, Sardella F, Dal-Monte A. The relationship of maximal alactacid anaerobic power to somatotype in trained subjects. Br J Sports Med 1985; 19:221-3.

9 Berg K, Latin RW, Coffey CH. Relationship of somatotype and physical characteristics to distance running performance in middle age runners. J Sports Med Phys Fitness 1998;38:253-7.

10 Durnin JVA, Womersley J. Body fat assessed from total body density and its estimation from skinfold thickness: measurements on 481 men and women aged from 16 to 72 years. Br J Nutr 1974;32:77-92.

11 Carter JEL, Heath BH. Somatotyping: development and applications. Cambridge: Cambridge University Press, 1990.

12 Ross WD, Hebbelink M, Brown SR et al. Kinanthropometric landmarks and terminology. In: Shephard RJ, Lavallée H, eds. Fitness assessment. Charles C. Thomas: Springfield IL, 1978:44-50.

13 Cazorla G, Léger L. Comment évaluer et développer vos capacités aérobies. Epreuve de course navette et épreuve Vam-éval. Bordeaux: AREAPS 1993:1-23.

14 Hansen JE, Sue DY, Oren A, et al. Relation of oxygen uptake to work rate in normal men and men with circulatory disorders. Am J Cardiol 1987;59(6):669-74.

15 Vandewalle H. Oxygen uptake and maximal oxygen uptake: interests and limits of their measurements. Ann Readapt Med Phys 2004;47(6):243-57.

16 Beaver WL, Wasserman K, Whipp BJ. A new method for detecting anaerobic threshold by gas exchange. J Appl Physiol 1986;60(6):2020-7.

17 Chamari K, Hachana Y, Ben Ahmed Y, et al. Field and laboratory testing in young elite soccer players. Br J Sports Med 2004;38(2):191-6.

18 Billat V, Renoux JC, Pinoteau J, et al. Reproducibility of running time to exhaustion at $\mathrm{V}_{2 \text { max }}$ in sub-elite runners. Med Sci Sports Exerc 1994;26(2):254-7.

19 Billat V, Pinoteau J, Petit B, et al. Calibration de la durée des répétitions d'une séance $\mathrm{d}^{\prime}$ interval training à la vitesse associée à $\mathrm{V}_{\mathrm{o}_{2 \max }}$ en référence au temps limite continu. Sci Motricité 1996;28:13-20.

20 Billat V, Flechet $B$, Petit $B$, et al. Interval training at $\dot{V}_{o_{2 m a x}}$ : effects on aerobic performance and overtraining markers in endurance athletes. Med Sci Sports Exerc 1999:31:156-63.

21 Galy O, Manetta J, Coste O, et al. Maximal oxygen uptake and power of lower limbs during a competitive season in triathletes. Scand J Med Sci Sports 2003;13:185-93.

22 Lacour JR, Padilla-Magunacelaya S, Chatard JC, et al. Assessment of running velocity at maximal oxygen uptake. Eur J Appl Physiol Occup Physiol $1991 ; 62: 77-82$.

23 Gibbons E, Jessup G, Wells T. Effects of various training intensity levels on anaerobic threshold and aerobic capacity in females. J Sports Med Phys Fitness 1983;23:315-8
24 Hickson RC, Hagberg JM, Ehsani AA. Time course of the adaptive responses of aerobic power and heart rate to training. Med Sci Sports Exerc 1981;13:17-20.

25 Åstrand PO, Rodahl K. Textbook of work physiology: physiological bases of exercise, 3rd ed. New York: McGraw-Hill, 2003.

26 Clausen JP. Effects of physical training on cardiovascular adjustments to exercise in man. Physiol Rev 1977;57:779-815

27 Daniels J, Scardina N, Hayes J, et al. Elite and subelite female middle- and long-distance runners. In: Landers DM, ed. Sport and elite performers. Champaign, IL: Human Kinetics, 1986:57-72.

28 Léger L, Mercier D, Gauvin L. The relationship between $\% \dot{V}_{o_{2 m a x}}$ and running performance time. In: Landers DM, ed. Sport and elite performers. Champaign, IL: Human Kinetics, 1986:113-20.

29 Berthoin S, Mantéca F, Lensel-Corbeil G, et al. Effect of a 12 week training program on maximal aerobic speed (MAS) and running time to exhaustion at $100 \%$ of MAS in school students aged 14 to 17 years. J Sports Med Phys Fitness 1995:35:251-6.

30 Jones AM, McConnell AM. Effect of exercise modality on oxygen uptake kinetics during heavy exercise. Eur J Appl Physiol 1999;80:213-19.

31 Carter $\mathbf{H}$, Jones AM, Doust JH. Effect of six weeks endurance training on the lactate minimum speed. J Sports Sci 1999;17:957-67.

32 Weltman A, Seip RL, Snead D, et al. Exercise training at and above the lactate threshold in previously un-trained women. Int J Sports Med 1992; 13:257-63.

33 Weston AR, Karamizrak O, Smith A, et al. African runners exhibit greater fatigue resistance, lower lactate accumulation, and higher oxidative enzyme activity. J Appl Physiol 1999;86:915-23.

34 Skibinska A, Sklad M. Genetic determination of Heath and Carter somatotype. Biol Sport 1984;1:37-53.

35 Bouchard C. Genetics of aerobic power and capacity. In: Malina RM, Bouchard C, eds. Sports and human genetics. Champaign. IL: Human Kinetics, 1986:59-88.

36 Montgomery HE, Marshall R, Hemingway $\mathrm{H}$, et al. Human gene for physical performance. Nature 1998;393(6682):221-2.

37 Léger $\mathrm{L}$, Bosquet $\mathrm{L}$, Folch $\mathrm{N}$. Évaluation et développement des aptitudes aérobies au cours de la croissance. In: Cazorla G, Robert G, eds. Actes du quatrième Colloque International de la Guadeloupe. Bordeaux: AREAPS, 1997:70-94.

38 Winter EM. Scaling partitioning out difference in size. Pediatr Exer Sci 1992;4:296-301.

39 Bergh V, Sjödin B, Forsberg A, et al. The relationship between body mass and oxygen uptake during running in humans. Med Sci Sports Exerc 1991;23:205-11.

40 Cavanagh P, Kram R. Mechanical and muscular factors affecting the efficiency of human movement. Med Sci Sports Exerc 1985; 17:326-31

41 Pate R, Macera C, Bailey S, et al. Physiological, anthropometric, and training correlates of running economy. Med Sci Sports Exerc 1992;24:1128-33.

42 Cureton KJ, Sparling PB, Evans BW, et al. Effect of experimental alterations in excess weight on aerobic capacity and distance running performance. Med Sci Sports 1978;10:194-9. 